\title{
NASTAVNI PREDMETI IZ DOMENA PREDŠKOLSKOG VASPITANJA U STUDIJSKIM PROGRAMIMA DEPARTMANA ZA PEDAGOGIJU NA FILOZOFSKOM FAKULTETU U NIŠU ${ }^{1}$
}

\author{
Zorica Stanisavljević Petrović ${ }^{2}$ \\ Univerzitet u Nišu, Filozofski fakultet, Departman za Pedagogiju
}

\begin{abstract}
Apstrakt: U radu se istražuje zastupljenost nastavnih predmeta iz oblasti institucionalnog vaspitanja dece predškolskog uzrasta u studijskim programima pedagogije na Filozofskom fakultetu Univerziteta u Nišu. U okviru teorijskog dela rada dat je prikaz razvoja studijskih programa pedagogije, od osnivanja do danas, na sva tri nivoa studija, sa posebnim osvrtom na nastavne predmete koji su usmereni ka obrazovanju budućih pedagoga u domenu predškolskog vaspitanja. U radu je korišćena deskriptivna metoda i tehnika analize sadržaja. Osnovne jedinice analize su status nastavnih predmeta i fond časova. Rezultati analize su pokazali da su nastavni predmeti koji se odnose na vaspitanje dece predškolskog uzrasta prisutni u svim studijskim programima i na svim nivoima studija. Nalazi ukazuju da je najveći broj promena u statusu predmeta i fondu časova obeležio studijske programe na nivou osnovnih akademskih studija, dok su znatno manje promene prisutne na nivou master i doktorskih akademskih studija. Dobijeni rezultati mogu biti polazna osnova za buduća istraživanja u cilju kreiranja studijskih programa u narednim ciklusima akreditacije.
\end{abstract}

Ključne reči: predškolska pedagogija, studijski program, nastavni predmet, obrazovanje pedagoga.

\section{Uvod}

Predškolska pedagogija kao nastavni predmet uglavnom se proučava u okviru studijskih programa na kojima se obrazuju budući pedagozi i vaspitači predškolskih ustanova. Mada je reč o relativno mladoj nastavno-naučnoj disciplini, tokom poslednjih decenija, ona je našla svoje mesto u svim programima koji su usmereni na vaspitanje i obrazovanje dece predškolskog uzrasta. Važna osobenost ove discipline je dinamika, koja se izražava u stalnom praćenju novih naučnih dostignuća iz ove

${ }^{1}$ Rad je nastao kao rezultat istraživanja u okviru projekta: „Razvoj i perspektive Departmana za pedagogiju Filozofskog fakulteta u Nišu“, br. 100/1-10-5-01, finansiranog od strane Filozofskog Fakulteta Univerziteta u Nišu.

${ }^{2}$ zorica.stanisavljevic.petrovic@filfak.ni.ac.rs 
i srodnih oblasti, kao i održavanje kontinuiteta sa bogatom praksom predškolskih ustanova. Takva konstatacija ukazuje da se u okviru ovog predmeta konstantno unose novine, kako bi se obogatilo obrazovanje studenata u cilju što adekvatnije pripreme za budući neposredni rad u praksi.

U tom kontekstu javlja se potreba za stalnim preispitivanjem postojećih studijskih programa, njihovim poređenjem sa prethodnim i trasiranje smernica za buduće promene koje bi doprinele razvoju nastavnih predmeta iz oblasti vaspitanja dece ranog uzrasta. U relevantnoj literaturi ukazuje sa na potrebu za analizom studijskih programa i sadržaja predmeta, pre svega u smislu usklađenosti sadržaja predmeta sa profesionalnim kompetencijama koje su neophodne za rad u praksi predškolskih ustanova (Petrovici \& Masari, 2014a; Petrovici \& Masari, 2014b). Shodno tome, analiza prethodnih programa može biti od značaja u smislu promišljanja, sticanja uvida i refleksije o prethodnim programima, kako bi se unele promene koje bi doprinele razvoju predmeta iz oblasti predškolskog vaspitanja i obrazovanja.

\section{Predškolska pedagogija kao polazište za razvoj nastavnih predmeta iz domena vaspitanja dece ranog uzrasta}

Kamenov (2002: 5) navodi da je predškolska pedagogija naučna disciplina, koja se bavi ,prikupljanjem, opisivanjem, kritičkim preispitivanjem i sistematizacijom činjenica i pojava u oblasti vaspitanja dece ranog uzrasta, kao i faktorima koji posredno ili neposredno, utiču na njihov razvoj od rođenja do polaska u školu. U skladu sa tim, osnovna funkcija ove pedagoške discipline je u utvrđivanju zakonitosti, kao i kauzalnih odnosa među pojavama prisutnim u oblasti ranog detinjstva. Saznanja do kojih se dolazi naučnim putem se uopštavaju, čime se konstruiše sistem saznanja u oblasti predškolskog vaspitanja i obrazovanja.

Mada se predškolska pedagogija najčešće određuje kao relativno mlada pedagoška disciplina, prve ideje o vaspitanju dece ranih uzrasta mogu se naći još u antičkoj Grčkoj, u delima poznatih filozofa Platona i Aristotela. Platon je konstituisao sistem vaspitanja dece ranih uzrasta, sa posebnim sadržajima i metodama, koji bi bio pod nadzorom države. Slično tome, Aristotel je rano detinjstvo smatrao važnom etapom u razvoju ličnosti i propisao preporuke za pravilan razvoj.

Za razvoj predškolske pedagogije posebno su značajne misli i dela J. A. Komenskog (1592-1670), Ž. Ž. Rusoa (1712-1778), F. Frebela (1782-1852), M. Montesori (1870-1952). Ideje klasika pedagogije danas čine polazišta za konstituisanje predškolske pedagogije, kao i drugih nastavnih predmeta iz ove oblasti. Predškolska pedagogija danas ima svoje mesto u sistemu pedagoških disciplina. Osim toga, ona je u uskoj vezi sa drugim naukama koje proučavaju dete i detinjstvo, poput psihologije, sociologije i antropologije.

Kao nastavna disciplina, predškolska pedagogija je od ključnog značaja za obrazovanje budućih predškolskih pedagoga i vaspitača predškolskih ustanova. Kao posebna naučna disciplina, ona je usko povezana sa drugim naukama i pedagoškim disciplinama koje se bave decom ranog uzrasta. Za konstituisanje predškolske peda- 
gogije kao nastavne i naučne discipline u našoj zemlji, nesumnjivo izuzetan značaj ima Aleksandra Marjanović, a kasnije i njeni sledbenici Mirjana Pešić i Emil Kamenov, koji su nastavili razvoj predškolske pedagogije na filozofskim fakultetima u Beogradu i Novom Sadu. Aleksandra Marjanović je dala osnovne postavke kojima se predškolska pedagogija određuje kao „teorijska osnova i sistem naučnih činjenica o vaspitanju predškolske dece“ (Marjanović, prema Kamenov, 2002: 19). U skladu sa tim iz nje se jasno izdvaja Metodika vaspitno-obrazovnog rada kao ,predškolska didaktika“ ili „praktična teorija vaspitanja“ u kojoj se razmatraju implikacije za neposredni rad vaspitača i predškolskih pedagoga u praksi. Ova opšta metodika sadrži integrisane sadržaje posebnih metodika u skladu sa Osnovama programa vaspitnoobrazovnog rada sa predškolskom decom (Osnove programa predškolskog vaspitanja i obrazovanja, 2019). Na osnovama Predškolske pedagogije razvijeni su i drugi nastavni predmeti kao što je Metodika rada pedagoga u predškolskim ustanovama, Sistemi i programi predškolskog vaspitanja, Otvoreni kurikulum, Integrisani kurikulum i brojni drugi, koji sada imaju svoje mesto u studijskim programima za obrazovanje vaspitača predškolskih ustanova i na filozofskim fakultetima u Beogradu, Novom Sadu, Kosovskoj Mitrovici i Nišu u okviru studijskih programa za pedagogiju.

\section{Predškolska pedagogija kao nastavni predmet na Departmanu za pedagogiju}

Na Filozofskom fakultetu u Nišu, Predškolska pedagogija je kao nastavni predmet zastupljena još u prvom studijskom programu na grupi za pedagogiju. Uporedo sa osnivanjem Grupe za pedagogiju u okviru studijskog programa, planirana je realizacija nastavnog predmeta Predškolska pedagogija, pre svega zahvaljujući činjenici da je određeni broj nastavnika prethodno radio na visokim školama za obrazovanje vaspitača. U prvom nastavnom planu koji je realizovan u akademskoj 2000/2001. godini, nastavni predmet Predškolska pedagogija je bio obavezan i zastupljen sa tri časa predavanja i dva časa vežbi $(3+2)$. Prema navodima Stanisavljević Petrović (2010), sadržaji u nastavnom programu su bili veoma slični sadržajima koji su se izučavali u okviru predmeta Predškolska pedagogija na Višim školama za obrazovanje vaspitača. U okviru ovog predmeta, studenti su pored redovnog pohađanja časova predavanja i vežbi imali za predispitnu obavezu seminarski rad, kao i obaveznu stručnu praksu u trajanju od dve nedelje. Stručna praksa je organizovana za studente III i IV godine studija. Kao i ostali nastavni predmeti i ovaj predmet se slušao tokom 2 semestra, nakon čega je bio organizovan usmeni ispit. Na kraju studija, kada polože sve ispite studenti su radili diplomski rad.

U akademskoj 2004/2005. godini, došlo je do promena u strukturi nastavnog plana i programa na Studijskoj grupi za pedagogiju. Prema navodima Matejević (2005: 249), ,strukturu novog nastavnog plana čine obavezni predmeti, podržavajući izborni predmeti i slobodni izborni predmeti koji su raspoređeni u okviru osam semestara." Prema ovom nastavnom planu, tokom prve tri godine studija, na svakoj godini studenti su mogli da izaberu dva izborna predmeta. U četvrtoj godini studija 
studenti su mogli u jednom semestru izabrati jedan od 6 ponuđenih modula, od kojih su jedan činili nastavni predmeti koji se bave vaspitanjem dece predškolskog uzrasta. Predškolska pedagogija i dalje ima status obaveznog predmeta na trećoj godini studija. Ona čini polaznu osnovu za studente koji se opredele za pohađanje Modula predškolske pedagogije.

Pored uvođenja izbornosti predmeta, druga važna promena koja je obeležila obrazovanje pedagoga na Filozofskom fakultetu u Nišu u ovom periodu je uvođenje modula. Jedan od 6 ponuđenih modula je Modul predškolske pedagogije. Ovaj modul je obuhvatio sledeće nastavne predmete: Metodika rada predškolskog pedagoga; Sistemi i programi predškolskog vaspitanja; Razvoj govora i jezičkog stvaralaštva predškolske dece. Nastava u okviru izabranog modula je trajala tokom jednog semestra, a pored obaveznih časova predavanja i vežbi organizovan je i praktični rad studenata u predškolskim ustanovama.

Uvođenje modula je dovelo do promena u organizaciji nastavnog rada. Naime, studenti su dva dana tokom radne nedelje provodili na fakultetu gde su pratili obavezna predavanja i vežbe. Na Modulu predškolske pedagogije, predavanja su bila zastupljena sa 4, a vežbe sa 6 časova. Preostala 3 dana u toku radne nedelje studenti su provodili u predškolskim ustanovama, gde su, $\mathrm{u}$ dogovoru sa pedagogom-mentorom realizovali zadatke koje su dobijali na predavanjima i vežbama. O svojim aktivnostima u predškolskoj ustanovi studenti su vodili dnevnike prakse i pisali izveštaje za koordinatora prakse. Ispitne aktivnosti su organizovane na kraju semestra, a studenti su osim pismenog i usmenog dela polagali i praktični deo, koji je obuhvatio njihovo učešće u radu predškolskih ustanova.

U ovom periodu, došlo je do promena na nivou univerziteskog obrazovanja, pod uticajem Bolonjske deklaracije (Anđelković i Stanisavljević Petrović, 2012; Maksimović i Stanisavljević Petrović, 2012; Masari \& Petrovici, 2014). Uporedo sa tim, došlo je do promena u sistemu studiranja na Studijskoj grupi za pedagogiju na Filozofskom fakultetu u Nišu (Matejević, 2005). U cilju usaglašavanja sa principima ovog dokumenta, na Departmanu za pedagogiju došlo je do promena na nivou evaluacije. Na svim godinama studija uvedena je „parcijalna evaluacija rada studenata" koja je bila usmerena ka konstantnom praćenju rada studenata tokom čitavog semestra. Uvođenje kontinuirane evaluacije je predstavljalo značajan korak napred u odnosu na ranije klasično ispitivanje studenata. Osim toga, došlo je i do drugih promena, koje se odnose na bogaćenje metoda rada, pre svega uvođenje interaktivnih metoda rada. Važna promena koja se desila u ovom periodu je menjanje položaja studenata u cilju aktivnijeg pozicioniranja studenta u nastavnom procesu. Takođe, ovaj period obeležava jačanje povezanosti i saradnje sa ustanovama za vaspitanje i obrazovanje. Studijski program na Departmanu za pedagogiju iz 2004/2005. godine imao je mnogobrojne prednosti u odnosu na prethodni. Među njima se izdvaja kontinuirana praksa studenta tokom čitavog semestra, što je dovelo do prevazilaženja jedne od najslabijih karika prethodnog programa - nedovoljan broj časova prakse. Studenti su jako dobro prihvatili ovakvu organizaciju rada, posebno kontiniranu evaluaciju, što je nesumnjivo dovelo do ostvarivanja bolje uspešnosti i efikasnosti u studiranju. Međutim, organizacija rada u programu sa modulima bila je praćena 
brojnim teškoćama: nedovoljan broj i povećano angažovanje nastavnika i saradnika za realizaciju nastave, teškoće u usklađivanju za zahtevima predškolskih ustanova i drugo. Osim toga, potrebno je dodati da je ovakva organizacija rada „bitno odudarala od okoštale fakultetske strukture" (Stanisavljević Petrović, 2010: 112), što navodi na pomisao da sredina još uvek nije bila spremna za neke krupnije promene.

U narednom studijskom programu, koji je akreditovan akademske 2007/2008. godine, ukinuti su moduli, a strukturu programa čine izborni i obavezni predmeti (Raspored predmeta po semestrima studijski program za pedagogiju akreditovan 2008 . godine). Važna novina u ovom periodu je da se nastava svih predmeta ograničava na trajanje od jednog semestra. U skladu sa tim, u V semestru se izučava predmet Predškolska pedagogija, koji je obavezan i zastupljen sa dva časa predavanja i dva časa vežbi $(2+2)$. U istom semestru nalazi se još jedan predmet namenjen vaspitanju dece ranog uzrasta Razvoj govora i stvaralaštva predškolske dece, zastupljen sa 2 časa predavanja i jednim časom vežbi nedeljno, koji je izbornog karaktera. U VI semestar uvodi se predmet Programi predškolskog vaspitanja, koji je nastao manjom modifikacijom predmeta Sistemi i programi predškolskog vaspitanja, a koji je bio u okviru Modula predškolska pedagogija. Ovaj predmet takođe ima status obaveznog predmeta i ima isti broj časova kao i predmet Predškolska padagogija (2+2). U VII semestru zastupljen je predmet Metodika rada pedagoga u predškolskim ustanovama, koji dobija status obaveznog predmeta i realizuje se sa dva časa predavanja i dva časa vežbi $(2+2)$. Stručna praksa u predškolskim ustanovama je zastupljena i u ovom programu u okviru predmeta Metodika rada pedagoga u predškolskim ustanovama sa 30 časova.

Tokom 2010. godine na Filozofskom fakultetu u Nišu su prvi put akreditovane diplomske akademske studije (Raspored predmeta po semestrima studijski program MAS pedagogije, 2010). U ovom programu nije zastupljena Predškolska pedagogija kao nastavni predmet, budući da se kao takav već nalazi na osnovnim akademskim studijama. U ovom nivou studija zastupljen je predmet Priprema dece za polazak $u$ $\check{s} k$ olu, koji je u statusu izbornog predmeta u drugom semestru. Nastavni predmet Priprema dece za polazak u školu je zastupljen sa 2 časa predavanja u Izbornom bloku 4. Na taj način je omogućeno studentima da mogu izabrati teme iz oblasti Predškolske pedagogije za izradu završnih radova.

Studijski program za pedagogiju koji je akreditovan 2014. godine ima veoma sličnu strukturu kao i prethodni (Raspored predmeta po semestrima studijski program za pedagogiju, 2014). U ovom studijskom programu nastavni predmet Predškolska pedagogija je obavezni predmet, i dalje se sluša na trećoj godini studija, gde je zastupljen sa 2 časa predavanja i 2 časa vežbi. U oviru Izbornog bloka 6, u istom semestru studenti mogu izabrati izborni predmet Razvoj govora i stvaralaštva predškolske dece, koji takođe ima fond časova 2+2. U VI semestru je i dalje zastupljen predmet Programi predškolskog vaspitanja, kao obavezni predmet sa fondom od 2+2 časa nedeljno. Stručna praksa iz oblasti predškolske pedagogije se realizuje u okviru Stručne prakse 1 (20 časova), na trećoj godini studija i Stručne prakse 2 iz predmeta Metodika rada pedagoga u predškolskim ustanovama, na četvrtoj godini studija (20 časova). Novina u ovom programu je da nakon položenih ispita studenti rade završni rad, za koji biraju teme u skladu sa interesovanjima. 
Tokom 2014. godine, akreditovan je i drugi program master akademskih studija, koji se sastoji od 2 modula: Modul Pedagogija i Modul Socijalana pedagogija (Raspored predmeta po semestrima studijski program master akademskih studija pedagogije, 2014). Iz oblasti predškolske pedagogije na oba ova modula, kao izborni predmet zastupljen je predmet Priprema dece za polazak u školu, sa 2 časa predavanja. U okviru oba modula predviđen je i završni rad studenata.

U akademskoj 2017. godini akreditovan je prvi program doktorskih akademski studija pedagogije na Filozofskom fakultetu u Nišu. U ovom programu jedini predmet iz oblasti vaspitanja dece ranog uzrasta je predmet Savremena pitanja predškolskog vaspitanja i obrazovanja. On je u statusu izbornog predmeta i zastupljen sa 5 časova predavanja i 2 časa samostalnog istraživačkog rada (Raspored predmeta po semestrima i godinama studija za studijski program DAS pedagogije, 2017).

Tokom 2020. i 2021. godine, došlo je do značajnih promena u organizaciji nastavnog procesa, usled pandemije izazvane virusom Covid 19. Naime, u skladu sa preporukama Ministarstva prosvete, kao i veći broj univerzitetskih ustanova i Filozofski fakultet $u$ Nišu je organizovao onlajn nastavu. Realizacija nastave na nov način nije uticala na ostvarivanje nastavnih planova, nasuprot tome, nastava i druge aktivnosti, uključujući i ispite, uspešno su realizovane i u novim okolnostima. U prilog tome, govori i podatak da je upravo u tom periodu pripremljen materijal za akreditaciju studijskih programa na Departmanu za pedagogiju na osnovnim i master akademskim studijama.

Početkom 2021. godine akreditovani su studijski programi za pedagogiju na osnovnim akademskim studijama i master studijama na Filozofskom fakultetu u Nišu, koji će se primenjivati od akademske 2021/2022. godine. Studijski program osnovnih akademskih studija je obogaćen novim predmetima, s obzirom na veći broj nastavnika u odnosu na prethodne periode. Nastavni predmet Predškolska pedagogija je i dalje u statusu obaveznog predmeta, sa fondom od $2+2$ časa nedeljno, na trećoj godini studija. I drugi predmeti iz ove oblasti zadržali su svoje pozicije koje su imali u prethodnom akreditovanom programu. Jedina značajna promena u predmetima u oblasti vaspitanja dece ranog uzrasta u ovom programu je zamena predmeta Priprema dece za polazak u školu. Umesto ovog predmeta uveden predmet Mediji u predškolskom obrazovanju. Status predmeta i dalje je ostao isti kao i fond časova.

\section{Metodološki okvir}

Osnovni cilj ovog istraživanja je utvrđivanje zastupljenosti, statusa i fonda časova nastavnih predmeta iz oblasti vaspitanja dece ranog uzrasta u studijskim programima za pedagogiju na Filozofskom fakultetu u Nišu. Kao nastavni predmeti iz oblasti vaspitanja dece ranog uzrasta, obuhvaćeni su svi predmeti sa sva tri nivoa studija i to: Predškolska pedagogija, Programi predškolskog vaspitanja, Razvoj govora i jezičkog stvaralaštva predškolske dece; Priprema dece za polazak u školu i Mediji u predškolskom obrazovanju i Savremena pitanja predškolskog vaspitanja i obrazovanja. Za istraživanje tretmana i postavljenosti ovih predmeta korišćeni su 
studijski programi od osnivanja Departmana za pedagogiju do danas. Konkretnije to su studijski programi OAS iz akademske 2000/2001; 2004/2005; 2007/2008; 2014/2015. i 2021. godine; zatim studijski programi MAS iz akademske 2010. i 2014. godine; kao i studijski program DAS, koji je akreditovan 2017. godine. Osnovna tehnika je analiza sadržaja studijskih programa za pedagogiju na svim nivoima studija. Uporedna analiza je urađena na osnovu sledećih jedinica analize: nivo studija, status predmeta (izborni ili obavezni), fond časova.

Istraživački zadaci:

1. Utvrditi zastupljenost predmeta iz oblasti vaspitanja dece ranog uzrasta $u$ studijskim programima za pedagogiju Filozofskog fakulteta u Nišu na sva tri nivoa studija (OAS, MAS, DAS).

2. Utvrditi status nastavnih predmeta iz oblasti vaspitanja dece ranog uzrasta u studijskim programima za pedagogiju Filozofskog fakulteta u Nišu.

3. Utvrditi fond časova predmeta iz oblasti vaspitanja dece ranog uzrasta $u$ studijskim programima za pedagogiju Filozofskog fakulteta u Nišu.

\section{Analiza sa diskusijom}

$\mathrm{Na}$ osnovu prethodnog kratkog prikaza promena u studijskim programima za pedagogiju, u Tabeli 1 sistematizovani su podaci o predmetima iz oblasti vaspitanja dece ranog uzrasta u studijskim programima na osnovnim akademskim studijama. $\mathrm{Na}$ osnovu podataka prikazanih u Tabeli 1 može se videti da je nastavni predmet Predškolska pedagogija, prisutan u svim studijskim programima, od osnivanja Studijske grupe za pedagogiju, odnosno od studijskog programa iz 2000/2001. godine. Ostali predmeti su zastupljeni u narednim programima, odnosno studijskim programima OAS pedagogije koji su usvojeni od 2004. godine pa na dalje. Predmet Razvoj govora i stvaralaštva predškolske dece je kao izborni predmet uveden u studijski programi iz 2004/2005. godine. On je u početku predstavljao sastavni deo Modula za predškolsku pedagogiju, zajedno sa predmetima Sistemi i programi predškolskog vaspitanja i Metodika rada predškolskog pedagoga. Od ovih predmeta u narednim studijskim programima, jedino se ne pojavljuje predmet Sistemi i programi predškolskog vaspitanja, čiji sadržaj je nakon ukidanja programa sa modulima, 2007/2008. godine, modifikovan. U skladu sa promenama u sadržaju predmeta sam predmet je dobio kraći naziv Programi predškolskog vaspitanja. Ovaj predmet je u studijskom programu iz 2007/2008. godine dobio status obaveznog predmeta i kao takav ostao na istoj poziciji u narednima studijskim programima na Departmanu za pedagogiju Filozofskog fakulteta u Nišu. Nastavni predmet Metodika rada predškolskog pedagoga, koji je bio u sastavu Modula za predškolsku pedagogiju u studijskom programu iz 2004/2005. godine je narednim programima dobio naziv Metodika rada pedagoga u predškolskim ustanovama i kao takav postao obavezni predmet, počev od studijskog programa koji je akreditovan 2008. godine, pa na dalje. 
Tabela 1. Nastavni predmeti u studijskim programima OAS pedagogije

\begin{tabular}{|c|c|}
\hline Naziv predmeta & Zastupljenost u studijskom programu OAS pedagogije \\
\hline \multirow{2}{*}{ Predškolska pedagogija } & Studijski programi OAS iz akademske 2000/2001; \\
\hline & 2004/2005; 2007/2008; 2014/2015. i 2021. godine \\
\hline \multirow{2}{*}{$\begin{array}{c}\text { Razvoj govora i stvaralaštva } \\
\text { predškolske dece }\end{array}$} & Studijski programi OAS iz akademske 2004/2005; \\
\hline & 2007/2008; 2014/2015. i 2021. godine \\
\hline \multirow{2}{*}{$\begin{array}{c}\text { Sistemi i programi predškolskog } \\
\text { vaspitanja }\end{array}$} & Studijski program OAS pedagogije iz akademske \\
\hline & $2004 / 2005$ \\
\hline \multirow{2}{*}{ Programi predškolskog vaspitanja } & Studijski program OAS pedagogije iz akademske \\
\hline & 2007/2008; 2014/2015. i 2021. godine \\
\hline \multirow{2}{*}{$\begin{array}{c}\text { Metodika rada predškolskog } \\
\text { pedagoga }\end{array}$} & Studijski program OAS pedagogije iz Akademske \\
\hline & 2004/2005; 2007/2008; 2014/2015. i 2021. godine \\
\hline \multirow{2}{*}{$\begin{array}{l}\text { Metodika rada pedagoga u } \\
\text { predškolskim ustanovama }\end{array}$} & Studijski program OAS pedagogije iz Akademske \\
\hline & 2007/2008; 2014/2015. i 2021. godine. \\
\hline
\end{tabular}

Osim ovih promena $\mathrm{u}$ odnosu na zastupljenost $\mathrm{i}$ status predmeta, tokom razvoja studijskih programa OAS pedagogije, javljale su se i promene vezane za fond časova u predmetima koji se bave vaspitanjem dece predškolskog uzrasta. Najznačajnije promene u fondu časova su primetne kada je uveden studijski program sa modulima, 2004/2005. godine, kada se s obzirom na specifičnu organizaciju fond časova povećao kod svih predmeta na Modulu za predškolsku pedagogiju, kada su časovi predavanja bili zastupljeni sa 4 , a vežbe sa 5 časova. Do promene u fondu časova dolazilo je i kod drugih predmeta, na primer nastavni predmet Predškolska pedagogija je u prvom studijskom programu iz 2000/2001. godine imao fond od tri časa predavanja i 2 časa vežbi (3+2). Kasnije, u studijskom programu iz 2008. godine, fond časova je uglavnom ujednačen na nivou departmana i fakulteta i za sve predmete je iznosio $2+2$, odnosno 2 časa predavanja koja prati isti broj časova vežbi.

Predmeti iz oblasti vaspitanja dece ranog uzrasta u studijskim programima MAS i DAS pedagogije na Filozofskom fakultetu Nišu prikazani su u Tabeli 2. Iz Tabele 2 se može videti da su u studijskim programima pedagogije na drugom nivou studija (master studije), iz 2010. i 2014. godine, predmeti iz oblasti vaspitanja dece ranog uzrasta zastupljeni sa samo jednim predmetom - Priprema dece za polazak u školu. Ovaj predmet je izbornog karaktera, zastupljen je sa 2 časa predavanja nedeljno na oba modula: Modul Pedagogija i Modul Socijalna pedagogija, koji su uvedeni 2014. godine. Predmet Priprema dece za polazak u školu je u novom ciklusu akreditacije, početkom 2021. godine zamenjen predmetom Mediji u predškolskom obrazovanju, pri čemu je fond časova ostao isti. Na trećem nivou studija, doktorske akademske studije, takođe postoji samo jedan predmet iz oblasti vaspitanja dece ranog uzrasta - Savremena pitanja predškolskog vaspitanja i obrazovanja. Ovaj predmet je izbornog karaktera i zastupljen sa 5 časova predavanja i 2 časa studijskog istraživačkog rada. 
Tabela 2. Nastavni predmeti iz oblasti vaspitanja dece ranog uzrasta na studijskim programima MAS i DAS pedagogije

\begin{tabular}{|c|c|c|}
\hline Naziv predmeta & Nivo studija & $\begin{array}{c}\text { Godina akreditacije } \\
\text { studijskog programa }\end{array}$ \\
\hline $\begin{array}{c}\text { Priprema dece za polazak u } \\
\text { školu }\end{array}$ & MAS & $2010 ; 2014$. \\
\hline $\begin{array}{c}\text { Mediji u predškolskom } \\
\text { obrazovanju }\end{array}$ & MAS & 2021. \\
\hline $\begin{array}{c}\text { Savremena pitanja } \\
\text { predškolskog vaspitanja i } \\
\text { obrazovanja }\end{array}$ & DAS & 2017. \\
\hline
\end{tabular}

\section{Zaključak}

$\mathrm{Na}$ osnovu prikaza razvoja studijskih programa za pedagogiju na Filozofskom fakultetu u Nišu, može se zaključiti da su u svim programima i na svim nivoima studija zastupljeni predmeti iz oblasti vaspitanja dece predškolskog uzrasta. Razlike se javljaju u broju i statusu predmeta, kao i fondu časova koji je predviđen za realizaciju. Broj predmeta na osnovnim akademskim studijama je značajno promenjen u odnosu na prvi studijski program iz 2000/2001. godine, kada je postojao samo jedan nastavni predmet koji se bavio vaspitanjem dece ranog uzrasta - Predškolska pedagogija. Takođe, primetna je tendencija za promenama i inoviranjem, koja je posebno vidljiva u periodu uvođenja studijskog programa sa modulima, tokom 2004/2005. godine, kada je značajno povećan broj nastavnih predmeta koji se odnose na vaspitanje dece predškolskog uzrasta. U kasnijim periodima u studijskim programima za pedagogiju je preovladavala potreba za usaglašavanjem, kako na nivou departmana, tako i na nivou fakulteta u celini, pre svega u smislu ujednačavanja fonda časova, časova stručne prakse i slično. Prilična odstupanja javljaju se u studijskom programu doktorskih akademskih studija pedagogije (DAS), u kome su predmeti zastupljeni sa 5 časova predavanja.

Može se zaključiti da su se najveće promene vezano za nastavne predmete koji se bave vaspitanjem dece predškolskog uzrasta dešavale na nivou osnovnih akademskih studija pedagogije. Od prvog studijskog programa koji je bio tradicionalno postavljen, do najnovijeg koji je akreditovan 2021. godine. Mada broj predmeta koji se bave institucionalnim vaspitanjem dece predškolskog uzrasta nije uvećan, pre svega zbog kadrovskih mogućnosti, uvođenje novog predmeta na master akademskim studijama, Mediji u predškolskom obrazovanju, načinjen je značajan iskorak u smislu podrške obrazovanju budućih pedagoga za istraživanje tema vezanih za vaninstitucionalne uticaje na razvoj, vaspitanje i obrazovanje predškolske dece. Uvođenje ovog predmeta zbog toga treba posmatrati kao pokušaj da se ide i korak sa tendencijama savremenog društva u kome dominiraju uticaji novih medijskih tehnologija. 
Na nivou Doktorskih akademskih studija pedagogije u važećem studijskom programu postoji samo jedan nastavni predmet koji se odnosi na vaspitanje dece ranog uzrasta - Savremena pitanja predškolskog vaspitanja i obrazovanja. Razlog takvom rešenju su kadrovski potencijali Departmana za pedagogiju, tačnije njihov nedostatak sa kojim se ovaj Departman nosi još od vremena njegovog osnivanja. U tom kontekstu hrabri činjenica da postoji interesovanje studenata doktorskih akademskih studija za ovu oblast i da će u narednim ciklusima akreditacije biti više prostora za predmete koji se bave vaspitanjem dece predškolskog uzrasta.

Limitiranost ovog rada se ogleda u činjenici da se u analizi Studijskih programa za pedagogiju na Filozofskom fakultetu u Nišu bavi samo predmetima koji se odnose na vaspitanje dece ranog uzrasta. Verujemo da bi analize drugih aspekata programa bile od značaja za sagledavanje realnog stanja i planiranje novih studijskih programa u narednim ciklusima akreditacije. S druge strane, doprinos ovog rada je što on čini prilog dokumetovanju razvoja Departmana za pedagogiju na Filozofskom fakultetu u Nišu, posebno u delu razvoja studijskih programa. Osim toga, ovaj rad pruža mogućnost refleksije i sticanja uvida o tretmanu i postavljenosti nastavnih predmeta iz oblasti vaspitanja dece predškolskog uzrasta u dosadašnjim studijskim programima, što može biti dobra osnova za različite analize i kreiranje daljih pravaca razvoja.

\section{Literatura}

Anđelković, S. i Stanisavljević Petrović, Z. (2012). Changes in University teaching - the road from knowledge to competencies. Pedagogika, 84(8), 1248-1259.

Kamenov, E. (2002). Predškolska pedagogija. Beograd: Zavod za udžbenike i nastavna sredstva.

Maksimović, J. i Stanisavljević Petrović, Z. (2012). Protivurečna iskustva studenata o dometima reforme visokog obrazovanja. Teme, 36(3), 1173-1189.

Masari, G. A. \& Petrovici, C. (2014). A critical perspective regarding pre-service teacher training and competences needed of kindergarten teachers from Romanian education system. Procedia-Social and Behavioral Sciences, 146, 22-27.

Matejević, M. (2005). Promene u sistemu studiranja na Studijskoj grupi za pedagogiju na Filozofskom fakultetu u Nišu. U: A. Mimica i Z. Grac (ur.). Visoko obrazovanje u Srbiji na putu ka Evropi - četiri godine kasnije (247-252). Beograd: Alternativna akademska obrazovna mreža.

Osnove programa predškolskog vaspitanja i obrazovanja (2019). Službeni glasnik RS, br. $27 / 2018$.

Petrovici, C. \& Masari, G. A. (2014a). Content analysis of syllabus for students of kindergarten and primary school pedagogy according to the professional competences. Procedia-Social and Behavioral Sciences, 146, 28-33.

Petrovici, C. \& Masari, G. A. (2014b). Aligning the academic teacher training curriculum for preschool and primary school education to the requirements of the RNCIS. Procedia-Social and Behavioral Sciences, 142, 731-737. 
Raspored predmeta po semestrima i godinama studija za Studijski program DAS pedagogije (2017). Preuzeto sa https://drive.google.com/drive/folders/1sfX4pZhfUbM1fM YSEpM2CToJ8vdWTwCC

Raspored predmeta po semstrima i godinama studija za Studijski program MAS pedagogije (2014). Preuzeto sa: https://drive.google.com/drive/folders/1Mr2tvaYcIc9--0TX7Lo0qOPUDyMn6VT

Raspored predmeta po semstrima za Studijski program MASpedagogije(2010). Preuzeto sa: https://drive.google.com/drive/folders/1GwEJreldrO7cyZe50Q0_uBkeKBwkov34

Raspored predmeta po semstrima za Studijski program OAS pedagogije (2014). Preuzeto sa: https://drive.google.com/drive/folders/1CLpZfXwdNPuvK16y1b_iGoue8Pzbgwa0

Raspored predmeta po semstrima za Studijski program OAS pedagogije (2008). Preuzeto sa: https://drive.google.com/drive/folders/1qs1ojGo4Zt07PYngtidbXBpbtHDKA rW1

Stanisavljević Petrović, Z. (2010). Promene u inicijalnom obrazovanju pedagoga za rad u predškolskim ustanovama. Nastava $i$ vaspitanje, 59(1), 101-115.

\title{
COURSES IN THE FIELD OF PRESCHOOL EDUCATION IN THE STUDY PROGRAMS OF THE DEPARTMENT OF PEDAGOGY AT THE FACULTY OF PHILOSOPHY IN NIŠ
}

\author{
Zorica Stanisavljević Petrović \\ University of Niš, Faculty of Philosophy, Department of Pedagogy
}

\begin{abstract}
The paper investigates the representation of subjects in the field of institutional education of preschool children in the pedagogy study programs at the Faculty of Philosophy, University of Nis. Within the theoretical part, the paper presents the development of pedagogy study programs, from its establishment until today, at all three levels of study, with special reference to the subjects that are directed toward the education of future pedagogues in the field of preschool education. The paper uses a descriptive method and content analysis technique. The basic units of analysis are the status of subjects and the number of classes. The results of the analysis showed that the subjects related to the education of preschool children are present in all study programs and at all levels of study. The findings indicate that the largest number of changes in the status of subjects and the number of classes marked study programs at the level of bachelor academic studies, while significantly smaller changes are present at the level of master's and doctoral academic studies. The obtained results can be a starting point for future research in order to create study programs in the next cycles of accreditation.
\end{abstract}

Key words: preschool pedagogy, study program, subject, pedagogue education. 
Citiranje članka:

Stanisavljević Petrović, Z. (2021). Nastavni predmeti iz domena predškolskog vaspitanja u studijskim programima Departmana za pedagogiju na Filozofskom fakultetu u Nišu. Godišnjak za pedagogiju, 6(1), 23-34. 